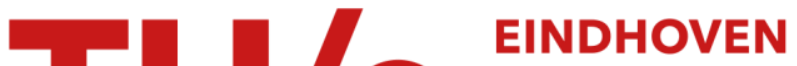 UNIVERSITY OF TECHNOLOGY
}

\section{In situ reaction mechanism studies of plasma-assisted atomic layer deposition of $\mathrm{Al} 2 \mathrm{O} 3$}

\section{Citation for published version (APA):}

Heil, S. B. S., Kudlacek, P., Langereis, E., Engeln, R. A. H., Sanden, van de, M. C. M., \& Kessels, W. M. M. (2006). In situ reaction mechanism studies of plasma-assisted atomic layer deposition of Al2O3. Applied Physics Letters, 89(13), 131505-1/3. [131505]. https://doi.org/10.1063/1.2357886

DOI:

$10.1063 / 1.2357886$

Document status and date:

Published: 01/01/2006

\section{Document Version:}

Publisher's PDF, also known as Version of Record (includes final page, issue and volume numbers)

\section{Please check the document version of this publication:}

- A submitted manuscript is the version of the article upon submission and before peer-review. There can be important differences between the submitted version and the official published version of record. People interested in the research are advised to contact the author for the final version of the publication, or visit the $\mathrm{DOI}$ to the publisher's website.

- The final author version and the galley proof are versions of the publication after peer review.

- The final published version features the final layout of the paper including the volume, issue and page numbers.

Link to publication

\section{General rights}

Copyright and moral rights for the publications made accessible in the public portal are retained by the authors and/or other copyright owners and it is a condition of accessing publications that users recognise and abide by the legal requirements associated with these rights.

- Users may download and print one copy of any publication from the public portal for the purpose of private study or research.

- You may not further distribute the material or use it for any profit-making activity or commercial gain

- You may freely distribute the URL identifying the publication in the public portal.

If the publication is distributed under the terms of Article 25fa of the Dutch Copyright Act, indicated by the "Taverne" license above, please follow below link for the End User Agreement:

www.tue.nl/taverne

Take down policy

If you believe that this document breaches copyright please contact us at:

openaccess@tue.nl

providing details and we will investigate your claim. 


\title{
In situ reaction mechanism studies of plasma-assisted atomic layer deposition of $\mathrm{Al}_{2} \mathrm{O}_{3}$
}

\author{
S. B. S. Heil ${ }^{\text {a) }}$ \\ Department of Applied Physics, Eindhoven University of Technology, P.O. Box 513, 5600 MB Eindhoven, \\ The Netherlands \\ P. Kudlacek \\ Department of Physics, West Bohemia University, P.O. Box 314, 30614 Plzen, Czech Republic \\ E. Langereis, R. Engeln, M. C. M. van de Sanden, and W. M. M. Kessels ${ }^{\text {b) }}$ \\ Department of Applied Physics, Eindhoven University of Technology, P.O. Box 513, 5600 MB Eindhoven, \\ The Netherlands
}

(Received 12 July 2006; accepted 4 September 2006; published online 28 September 2006)

\begin{abstract}
Reaction mechanisms during plasma-assisted atomic layer deposition (ALD) of $\mathrm{Al}_{2} \mathrm{O}_{3}$ from $\mathrm{Al}\left(\mathrm{CH}_{3}\right)_{3}$ and $\mathrm{O}_{2}$ plasma were studied by time-resolved quartz crystal microbalance measurements, mass spectrometry, and optical emission spectroscopy. $\mathrm{Al}\left(\mathrm{CH}_{3}\right)_{3}$ chemisorption on the oxide surface after the plasma pulse releases $\mathrm{CH}_{4}$ products while from the detection of $\mathrm{CO}, \mathrm{CO}_{2}$, and $\mathrm{H}_{2} \mathrm{O}$ in the $\mathrm{O}_{2}$ plasma it is established that surface $-\mathrm{CH}_{3}$ groups are predominantly removed by $\mathrm{O}$ radical-driven combustionlike reactions. Also a second pathway exists for $-\mathrm{CH}_{3}$ removal driven by $\mathrm{H}_{2} \mathrm{O}$ generated in this plasma step. These reaction pathways are expected to be generic for plasma-assisted ALD of oxides from metal organic precursors. (c) 2006 American Institute of Physics. [DOI: 10.1063/1.2357886]
\end{abstract}

The search for appropriate high- $k$ dielectrics for semiconductor applications has made atomic layer deposition (ALD) of oxides a very active research field. Recently, the investigations have been extended to ALD processes in which the commonly used $\mathrm{H}_{2} \mathrm{O}$ dosing step is replaced by $\mathrm{O}_{3}$ dosing or $\mathrm{O}_{2}$ plasma exposure, because of potential advantages such as improved film quality, increased flexibility in process conditions, and feasibility of lower deposition temperatures. For the pure thermal process, the reaction mechanisms underlying film growth have been investigated for several materials but for the $\mathrm{O}_{3}$-based or plasma-assisted ALD process virtually no dedicated studies have appeared yet. Especially the thermal process for $\mathrm{Al}_{2} \mathrm{O}_{3}$ ALD from trimethylaluminum $\left[\mathrm{Al}\left(\mathrm{CH}_{3}\right)_{3}\right]$ and $\mathrm{H}_{2} \mathrm{O}$, which can be considered as a model system for ALD, ${ }^{1}$ has been examined quite thoroughly both experimentally and theoretically. ${ }^{2-9}$ Details about the reaction mechanism have been established for this process, which is ruled by (i) chemisorption of $\mathrm{Al}\left(\mathrm{CH}_{3}\right)_{3}$ on $-\mathrm{OH}$ surface groups forming adsorbed $\left(-\mathrm{O}-{ }_{n} \mathrm{Al}\left(\mathrm{CH}_{3}\right)_{3-n}\right.$ by splitting off one of more ligands in the form of $\mathrm{CH}_{4}$ and (ii) the oxidation of the metal by $\mathrm{H}_{2} \mathrm{O}$ regenerating $-\mathrm{OH}$ surface groups while forming $\mathrm{CH}_{4}$.

In this letter, we report on the reaction mechanism of plasma-assisted $\mathrm{ALD}$ of $\mathrm{Al}_{2} \mathrm{O}_{3}$ by $\mathrm{Al}\left(\mathrm{CH}_{3}\right)_{3}$ and $\mathrm{O}_{2}$ plasma. In situ diagnostics such as quartz crystal microbalance and quadrupole mass spectrometry were employed and also optical emission spectroscopy was shown to provide unique time-resolved information. Details of the chemisorption step of $\mathrm{Al}\left(\mathrm{CH}_{3}\right)_{3}$ are presented and key insight about the removal of $-\mathrm{CH}_{3}$ ligands by the plasma is provided by revealing combustionlike reactions by $\mathrm{O}$ radicals. Such reactions have been hypothesized for metal organic precursors earlier, but with-

\footnotetext{
${ }^{a)}$ Electronic mail: s.b.s.heil@tue.nl

${ }^{\text {b) }}$ Author to whom correspondence should be addressed; electronic mail: w.m.m.kessels@tue.nl
}

out experimental support. It is also shown that reaction products created by the plasma (particularly $\mathrm{H}_{2} \mathrm{O}$ ) can lead to concurrent reaction pathways at the surface and that reaction products can significantly affect the plasma properties.

The experiments were carried out in a remote-plasma ALD system with an inductively coupled plasma source. A continuous flow of $\mathrm{O}_{2}$ serves both as plasma gas and as purge gas. $\mathrm{Al}\left(\mathrm{CH}_{3}\right)_{3}$ dosing and plasma exposure are alternated by releasing a trapped volume of $\mathrm{Al}\left(\mathrm{CH}_{3}\right)_{3}$ at room temperature and by pulsing $100 \mathrm{~W}$ plasma power for $2 \mathrm{~s}$, respectively. During the cycle the background pressure was kept constant at $\sim 10 \mathrm{mTorr}$ and the deposition temperature was set at $70^{\circ} \mathrm{C}$ by the wall heating of the reactor. Film growth was monitored by a quartz crystal microbalance (QCM) with a bakeable crystal holder positioned close to the substrate holder. The gold covered quartz crystals were first coated with $\mathrm{Al}_{2} \mathrm{O}_{3}$ before taking any data. The reaction products were sampled by a differentially pumped quadrupole mass spectrometer (QMS) fitted at the side of the reactor while plasma emission just above the substrate holder was detected by optical emission spectroscopy (OES). All diagnostics were operated simultaneously and their data acquisition rate was set to $10 \mathrm{~Hz}$. In these experiments the intermitted purge times were set as such to allow for a detailed study by the diagnostics. The $\mathrm{Al}_{2} \mathrm{O}_{3}$ material properties obtained with this experimental setup have been reported. ${ }^{10,11}$

A typical example of the mass change during the plasma-assisted ALD cycles as measured by the QCM is shown in Fig. 1(a). When pulsing the $\mathrm{Al}\left(\mathrm{CH}_{3}\right)_{3}$ in the reactor, the chemisorption of $\mathrm{Al}\left(\mathrm{CH}_{3}\right)_{3}$ on the surface can be observed as a sharp increase in mass $\left(m_{1}\right)$ which takes place within the time resolution of the QCM $(100 \mathrm{~ms})$. When the plasma is turned on, first a large negative spike is observed in the QCM signal followed by a recovery of the signal to a slightly higher level in mass $\left(m_{2}\right)$ than after $\mathrm{Al}\left(\mathrm{CH}_{3}\right)_{3}$ chemisorption. The spike during plasma exposure can be attributed 


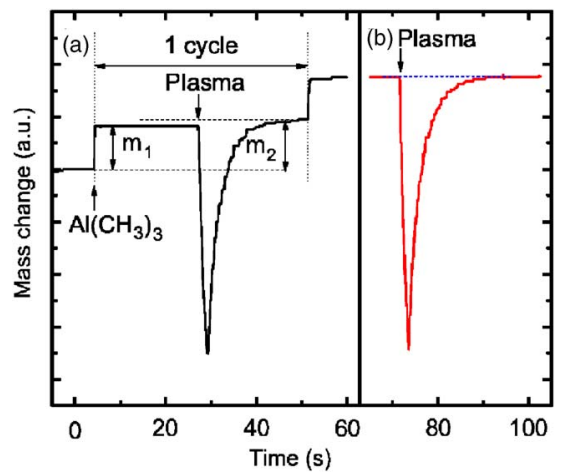

FIG. 1. (Color online) Apparent mass change as determined from the QCM signal for (a) an ALD cycle including $\mathrm{Al}\left(\mathrm{CH}_{3}\right)_{3}$ dosing and $\mathrm{O}_{2}$ plasma exposure and (b) only $\mathrm{O}_{2}$ plasma exposure.

to an artifact caused by the plasma, most probably due to charging of the crystal. The spike is also observed when exposing the QCM just to a plasma pulse as shown in Fig. 1(b); however, in this case the signal returns exactly to its starting level before the plasma pulse. The mass increase after the plasma step, $m_{2}-m_{1}$, can therefore be attributed to the replacement of $-\mathrm{CH}_{3}$ ligands by oxide surface groups.

From the ratio of the mass increase in the two half reactions, the fraction of ligands released during the $\mathrm{Al}\left(\mathrm{CH}_{3}\right)_{3}$ pulse can be estimated following the approach proposed by Rahtu and Ritala. ${ }^{12}$ In the present case, at $70{ }^{\circ} \mathrm{C}, \sim 1.8$ methyl $\left(-\mathrm{CH}_{3}\right)$ groups per chemisorbed $\mathrm{Al}\left(\mathrm{CH}_{3}\right)_{3}$ molecule are released indicating that the $\mathrm{Al}\left(\mathrm{CH}_{3}\right)_{3}$ mainly binds bifunctionally on the surface creating predominantly $(-\mathrm{O}-)_{2} \mathrm{Al}\left(\mathrm{CH}_{3}\right)$ surface groups. This is similar to what has been reported for thermal ALD $\left(150-350{ }^{\circ} \mathrm{C}\right)$ by $\mathrm{QCM}^{6}$ Remarkably different is, however, that the growth rate as determined from the QCM measurements (54 $\mathrm{ng} \mathrm{cm}^{-2} /$ cycle) as well as from in situ spectroscopic ellipsometry $\left(1.7 \AA\right.$ /cycle) is much higher than for $\mathrm{H}_{2} \mathrm{O}$ (32 $\mathrm{ng} \mathrm{cm}^{-2} /$ cycle or $1.1 \AA /$ cycle) (Ref. 4) or $\mathrm{O}_{3}$ (1.1 A/cycle) (Ref. 13) based processes at $\sim 70{ }^{\circ} \mathrm{C}$. A higher growth rate per cycle has been reported earlier for both remote and direct plasmas, ${ }^{14,15}$ and we attribute this higher growth rate to the availability of a higher number of reactive oxide surface groups for $\mathrm{Al}\left(\mathrm{CH}_{3}\right)_{3}$ chemisorption after the $\mathrm{O}_{2}$ plasma.

Figure 2 shows the QMS signal recorded for selected mass-to-charge $(\mathrm{m} / \mathrm{z})$ ratios during several ALD cycles. The most likely parent molecules leading to the different signals, which can either be due to direct or dissociative ionization of the corresponding molecule, are indicated. During $\mathrm{Al}\left(\mathrm{CH}_{3}\right)_{3}$ pulsing, the signal at $m / z=15$ and 16 increases which can be attributed to the detection of $\mathrm{CH}_{4}$ released during $\mathrm{Al}\left(\mathrm{CH}_{3}\right)_{3}$ chemisorption at the oxide surface. In principle, also the dissociative ionization of $\mathrm{Al}\left(\mathrm{CH}_{3}\right)_{3}$ contributes to the signal at $m / z=15$ but it was established that this contribution was negligible under the current conditions in which the amount of $\mathrm{Al}\left(\mathrm{CH}_{3}\right)_{3}$ dosed is just sufficient to saturate the surface reactions at the substrate and reactor's wall. For high overexposures of $\mathrm{Al}\left(\mathrm{CH}_{3}\right)_{3}$, i.e., with a significant amount of gaseous $\mathrm{Al}\left(\mathrm{CH}_{3}\right)_{3}$ in the reactor, a signal appeared at $\mathrm{m} / \mathrm{z}$ $=27\left(\mathrm{Al}^{+}\right)$with a minor contribution at $m / z=15$. Furthermore, the relative increase at $m / z=15$ and 16 in Fig. 2 is in good agreement with the cracking pattern of $\mathrm{CH}_{4}$ in the QMS. It can therefore be concluded that $\mathrm{Al}\left(\mathrm{CH}_{3}\right)_{3}$ chemiDownloaded 13 Sep 2007 to 131.155.108.71. Redistribution subject

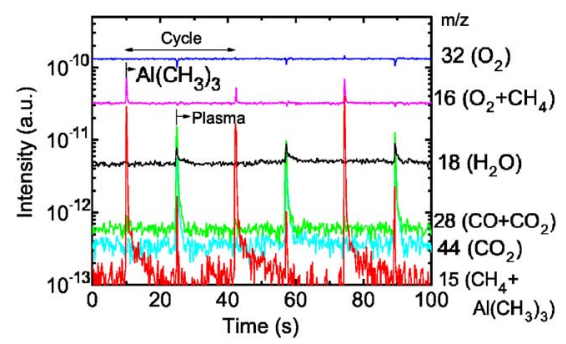

FIG. 2. (Color online) Time-resolved mass spectrometry signals for several ALD cycles. The most likely parent molecules contributing to the signals at the selected mass-to-charge ratios $\mathrm{m} / \mathrm{z}$ are indicated.

sorption at the surface releases $-\mathrm{CH}_{3}$ groups by a reaction between the $-\mathrm{CH}_{3}$ and hydrogen at the surface, e.g., by chemisorption of $\mathrm{Al}\left(\mathrm{CH}_{3}\right)_{3}$ on $-\mathrm{OH}$ surface groups.

During the plasma step, the signals at $m / z=18,28$, and 44 increase indicating the detection of $\mathrm{H}_{2} \mathrm{O}, \mathrm{CO}$, and $\mathrm{CO}_{2}$ reaction products. The signal at $m / z=28$ can partly be attributed to dissociative ionization of $\mathrm{CO}_{2}$ in the QMS, but from the cracking pattern and calibration measurements it has been established that $\mathrm{CO}$ is also present in the plasma. From these observations it can be concluded that the $-\mathrm{CH}_{3}$ groups existing at the surface after $\mathrm{Al}\left(\mathrm{CH}_{3}\right)_{3}$ chemisorption are removed from the surface by combustionlike reactions. These reactions as well as the oxidation of the $\mathrm{Al}$ are predominantly driven by the abundant $\mathrm{O}$ radicals in the plasma. ${ }^{16}$ This consumption of $\mathrm{O}$ radicals affects the $\mathrm{O}_{2}$ mass balance in the plasma and leads to a reduction of the $\mathrm{O}_{2}$ signal in the initial phase of the plasma step as can be observed at $m / z=16$ and 32.

During the $\mathrm{O}_{2}$ plasma pulse also an increase in the signal at $m / z=15$ is observed. Closer observation of the data reveals that this signal is observed for a significantly shorter duration than the signals at $m / z=18,28$, and 44 (about twice as short). We attribute the signal to $\mathrm{CH}_{4}$ released from the surface by the interaction of $\mathrm{H}_{2} \mathrm{O}$ produced by the combustionlike reactions with $-\mathrm{CH}_{3}$ surface groups. This forms a concurrent reaction path to the combustionlike process once $\mathrm{H}_{2} \mathrm{O}$ is produced but only when still a considerable amount of $-\mathrm{CH}_{3}$ groups is present at the surface. This indirect "thermal ALD" reaction becomes insignificant when the combustionlike reactions have removed most of the $-\mathrm{CH}_{3}$ groups. It should be noted that the detection of $\mathrm{CH}_{4}$ at $m / z=16$ is obscured by the consumption of $\mathrm{O}_{2}$ during the plasma pulse. Furthermore, we were not able to observe the formation of larger hydrocarbons, $\mathrm{C}_{x} \mathrm{H}_{y}$, in the plasma as, for example, suggested by Elliot et al. for the interaction between $\mathrm{O}$ atoms and $-\mathrm{CH}_{3}$ groups. ${ }^{17}$

Due to the relatively low pressure in the plasma, it can be assumed that the $\mathrm{CO}_{2}$ and $\mathrm{H}_{2} \mathrm{O}$ observed are predominantly formed by the reaction between $\mathrm{O}$ radicals and $-\mathrm{CH}_{3}$ ligands. The $\mathrm{CO}$ in the plasma can, however, be a product from incomplete combustion reactions or be produced in the plasma by electron-impact dissociation of $\mathrm{CO}_{2}$. Calibration experiments using plasmas in $\mathrm{CO} / \mathrm{O}_{2}$ and $\mathrm{CO}_{2} / \mathrm{O}_{2}$ mixtures showed that a significant level of $\mathrm{CO}$ is also created in a $\mathrm{CO}_{2}$-based plasma. Furthermore, it was determined that the amounts of $\mathrm{CO}$ and $\mathrm{CO}_{2}$ in the initial phase of the $\mathrm{O}_{2}$ plasma after $\mathrm{Al}\left(\mathrm{CH}_{3}\right)_{3}$ dosing reach levels of $\sim 7 \%$ of the total gas density.

The excitation of the plasma species gives also insight into the plasma-assisted ALD process. In Fig. 3(a) the emisto AIP license or copyright, see http://apl.aip.org/apl/copyright.jsp 

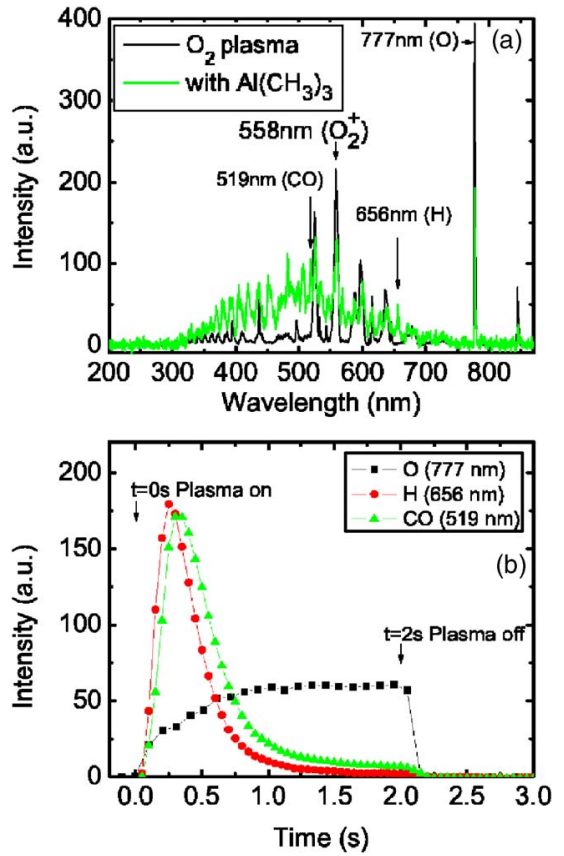

FIG. 3. (Color online) (a) Emission from a pure $\mathrm{O}_{2}$ plasma and an $\mathrm{O}_{2}$ plasma ignited after a preceding $\mathrm{Al}\left(\mathrm{CH}_{3}\right)_{3}$ dose as recorded in the first $200 \mathrm{~ms}$ after the plasma strike. (b) Time-resolved signal of selected emission lines during the $\mathrm{O}_{2}$ plasma step after a preceding $\mathrm{Al}\left(\mathrm{CH}_{3}\right)_{3}$ dose.

sion spectrum of a pure $\mathrm{O}_{2}$ plasma is shown. Mainly emission by $\mathrm{O}_{2}^{+}$from the first $\left(b^{4} \Sigma_{g}^{-} \rightarrow a^{4} \Pi_{u}\right)$ and second $\left(A^{2} \Pi_{u} \rightarrow X^{2} \Pi_{g}\right)$ negative systems and by $\mathrm{O}$ radicals $\left({ }^{5} P\right.$ $\rightarrow{ }^{5} S, 777 \mathrm{~nm}$ and $\left.{ }^{3} P \rightarrow{ }^{3} S, 845 \mathrm{~nm}\right)$ can be observed. When an $\mathrm{Al}\left(\mathrm{CH}_{3}\right)_{3}$ dose has preceded the plasma exposure, the emission in the first hundreds of milliseconds of the plasma pulse is remarkably different from the pure $\mathrm{O}_{2}$ plasma. As also shown in Fig. 3(a) there is an intense broadband emission in the first $200 \mathrm{~ms}$ of the plasma pulse which can sclearly be observed by the naked eye as a "blue flash." 18 At the end of the plasma pulse the emission is identical to the emission of a pure $\mathrm{O}_{2}$ plasma. The difference in emission at the start of the plasma pulse can be attributed to the plasma excitation of reaction products released from the surface which evidently disappears when the surface reactions are saturated. From the identification of the spectral lines, we found that the broadband emission is coming predominantly from CO (with the Ångström and Herzberg systems most prominent). Furthermore, also emission by atomic hydrogen $\left(\mathrm{H}_{\alpha}\right)$ can clearly be observed which is due to electron-impact dissociation of the $\mathrm{H}_{2} \mathrm{O}$ and $\mathrm{CH}_{4}$ reaction products.

Figure 3(b) shows time-resolved emission signals of the reaction products (CO Ångström system $\nu-\nu^{\prime}=0-2$ and $\mathrm{H}_{\alpha}$ ) and of the $\mathrm{O}$ radicals $\left(3 p^{5} P \rightarrow 3 s^{5} S\right)$ in the plasma. From the time-resolved signal of $\mathrm{H}$ and $\mathrm{CO}$, for which 1/e-decay times of $\sim 300$ and $\sim 500 \mathrm{~ms}$ can be determined, respectively, it can be concluded that the surface reactions during the plasma step are saturated well within $1 \mathrm{~s}$. This is in agreement with results obtained by in situ spectroscopic ellipsometry showing saturation of the growth rate for plasma pulses of $>0.5 \mathrm{~s}$. The time-resolved emission from $\mathrm{O}$ radicals shows that oxygen is consumed by the surface reactions generating the $\mathrm{CO}, \mathrm{CO}_{2}$, and $\mathrm{H}_{2} \mathrm{O}$ reaction products as well as by oxidizing the $\mathrm{Al}$ on the surface.

In summary, for the plasma-assisted ALD process of $\mathrm{Al}_{2} \mathrm{O}_{3}$ it has been established that the $\mathrm{O}_{2}$ plasma removes
$-\mathrm{CH}_{3}$ ligands from the surface mainly by combustionlike reactions driven by $\mathrm{O}$ radicals although a concurrent thermal-ALD-like reaction path by $\mathrm{H}_{2} \mathrm{O}$ generated by the plasma is also present. The subsequent chemisorption step of $\mathrm{Al}\left(\mathrm{CH}_{3}\right)_{3}$ on the surface appears to be similar as for thermal ALD albeit at a higher saturation level. Apparently, after the $\mathrm{O}_{2}$ plasma exposure a higher number of reactive oxide surface groups are available for $\mathrm{Al}\left(\mathrm{CH}_{3}\right)_{3}$ chemisorption. Whether these oxide surface groups after $\mathrm{O}_{2}$ plasma exposure are predominantly $-\mathrm{OH}$ groups such as in the thermal ALD process cannot be concluded from the present data. However, the release of $\mathrm{CH}_{4}$ during $\mathrm{Al}\left(\mathrm{CH}_{3}\right)_{3}$ chemisorption indicates the availability of hydrogen at the surface and surface $-\mathrm{OH}$ groups are likely to be formed in the reaction by the $\mathrm{H}_{2} \mathrm{O}$ created in the combustionlike reactions. The reaction mechanism discussed is expected to have generic relevance for plasma-assisted ALD processes of other oxides from metal organic precursors and the insight presented has important implications for processing, e.g., in terms of growth rate per cycle for plasma-assisted ALD. Furthermore, it is shown that reaction products from the plasma can significantly affect the plasma properties and hardware settings (e.g., power coupling) while a technique such as optical emission spectroscopy yields unique opportunities to study and optimize the properties for plasma-assisted ALD processes.

The authors would like to thank A. Rahtu (ASM Microchemistry) for his assistance with the QCM measurements and stimulating discussions. The Dutch Technology Foundation STW is acknowledged for their financial support. The research of one of the authors (W.M.M.K.) was made possible by a fellowship from the Royal Netherlands Academy of Arts and Sciences (KNAW).

${ }^{1}$ R. L. Puurunen, J. Appl. Phys. 97, 121301 (2005).

${ }^{2}$ S. M. George, A. W. Ott, and J. W. Klaus, J. Phys. Chem. 100, 13121 (1996).

${ }^{3}$ M. Ritala, H. Saloniemi, M. Leskelä, T. Prohaska, G. Friedbacher, and M. Grasserbauer, Thin Solid Films 286, 54 (1996).

${ }^{4}$ M. D. Groner, F. H. Fabreguette, J. W. Elam, and S. M. George, Chem. Mater. 16, 639 (2004).

${ }^{5}$ A. W. Ott, J. W. Klaus, J. M. Johnson, and S. M. George, Thin Solid Films 292, 135 (1997).

${ }^{6}$ A. Rahtu, T. Alaranta, and M. Ritala, Langmuir 17, 6506 (2001).

${ }^{7}$ M. Juppo, A. Rahtu, M. Ritala, and M. Leskelä, Langmuir 16, 4034 (2000).

${ }^{8}$ S. D. Elliot and J. C. Greer, J. Mater. Chem. 14, 3246 (2004).

${ }^{9}$ Y. Widjaja and C. B. Musgrave, Appl. Phys. Lett. 80, 3304 (2002).

${ }^{10}$ E. Langereis, M. Creatore, S. B. S. Heil, M. C. M. van de Sanden, and W. M. M. Kessels, Appl. Phys. Lett. 89, 081915 (2006).

${ }^{11}$ B. Hoex, S. B. S. Heil, E. Langereis, M. C. M. van de Sanden, and W. M. M. Kessels, Appl. Phys. Lett. 89, 042112 (2006).

${ }^{12}$ A. Rahtu and M. Ritala, Chem. Vap. Deposition 8, 21 (2002).

${ }^{13}$ S. K. Kim, S. W. Lee, C. S. Hwang, Y.-S. Min, J. Y. Won, and J. Jeong, J. Electrochem. Soc. 153, F69 (2006).

${ }^{14}$ A. Niskanen, K. Arstilla, M. Ritala, and M. Leskelä, J. Electrochem. Soc. 152, F90 (2005).

${ }^{15}$ S. J. Yun, J. W. Lim, and J.-H. Lee, Electrochem. Solid-State Lett. 7, C13 (2004).

${ }^{16}$ J. T. Gudmundsson, I. G. Kouznetsov, K. K. Patel, and M. A. Lieberman, J. Phys. D 34, 1100 (2001).

${ }^{17}$ S. D. Elliott, G. Scarel, C. Wiemer, M. Fanciulli, and G. Pavia, Chem. Mater. 18, 3764 (2006)

${ }^{18}$ See EPAPS Document No. E-APPLAB-89-331639 for a movie of the plasma emission during a plasma-assisted ALD cycle. This document can be reached through a direct link in the online article's HTML reference section or via the EPAPS homepage (http://www.aip.org/pubservs/ epaps.html). 